\title{
Sustainable development of the transportation system and infrastructure in Budapest
}

\begin{abstract}
The increasing number of citizens and rising number of tourists in Budapest contribute to the excessive use of the transport system. However, we should emphasize, that the number of tourists and citizens are growing year after year in the agglomerations of $\mathrm{Bu}$ dapest which have also impacted the sustainability of the transport system in Budapest (just think about daily commuters for example).

The aim of this paper is to assess the opinion of the citizens of Budapest about what they think the most disturbing aspects of the increasing traffic are and what kind measures would be required in the interest of a more sustainable transport system in our capital.
\end{abstract}

Keywords: sustainability, Budapest, overtourism, transport, sustainable transport

\section{Introduction}

The number of residents in the capital grew by 2,3\% between 2009 and 2019. On top of that, the number of the population in Pest County also grew by $5,4 \%$ in the observed period. If we look at the distribution of the population, we can see that $18 \%$ of Hungary's population live in Budapest and 13\% live in Pest County. Based on the research of the Hungarian Central Statistical Office (2016) 16,8\% of all commuters in Hungary travel to Budapest for work on a daily basis which means that more than 200.000 citizens use the transport system and infrastructure of the capital.

1 PhD student, Hungarian University of Agriculture and Life Sciences; e-mail: 89daniel.horvath@gmail.com DOI: http://dx.doi.org/10.31570/Prosp 2021_1_2 
Furthermore an increasing number of tourists is also registered by the service sector. Between 2009 and 2019 the registered number of tourists in commercial accommodations grew by $97 \%$ which means that an increasing number of visitors use the infrastructure. The phenomenon of overtourism can be seen in Budapest as well, just like in other bigger cities in Europe such as in Amsterdam or Barcelona. The density and intensity of tourism clearly show, that tourism in Budapest is getting more and more excessive. While tourism density was 6.960 tourists/ $\mathrm{km} 2$, the indicator grew to 8.139 tourists/km2 in 2018 which means that an increasing number of tourists appeared in the capital per square kilometre year after year. If we take the intensity into consideration, we see that 1,62 tourists per citizen were registered in 2011 and this indicator grew to 2,4 tourists per 1 citizen.

According to the Hungarian Central Statistical Office's (2019) numbers, there was a slight decrease in the number of the flights at the Liszt Ferenc International Airport between 2009 and 2019, however, in total the number of arrivals and departures grew by $10 \%$. This growing number also means more pollution (such as $\mathrm{CO} 2$ ) and noise as well. It was one of the main reasons why arrivals and departures were banned between 24:00 - 05:00 from August 2019 (turizmus.com, 2019). It was one step forward to ensure the comfortable life of citizens around the airport; however, this may affect the turnover of the airport negatively.

The research of the Danube Region Strategy (2019) proves that the number of the ships operating on the Danube grew from 124 to 170 between 2012 and 2017 which means a $37 \%$ growth. For the year 2020 organizers planned around 397 programs including 3012 departures (of course, organizers did not calculate with the pandemic). $79,84 \%$ of the announced departures would have reached Hungary as well. Budapest is mainly the starting or final destination of these trips (Jászberényi 2019) which means that these tourists also impact the transportation of Budapest during their visit.

When we examine the number of registered cars we see that the number of vehicles grew by $26 \%$ in Hungary between 2009 and 2019 (Hungarian Central Statistical Office, 2020a). The intensity of the growth was slower in Budapest (18\%) compared to the whole country. However, the intensity in Pest County was higher (35\%) than in the whole country or Budapest. Despite the growth of the number of cars in the observed period, the ratio of registered cars in Budapest decreased from 19\% to $18 \%$ between 2009 and 2019. One of the reasons is the larger growth intensity on a country basis. If we examine the average number of cars per person, we see a slight decrease between 2009 and 2019. While the average number of cars was 2,94 per person in Budapest in 2009, this indicator decreased to 2,56 per person by 2019 . 
If we review the statistics of the Hungarian Central Statistical Office (2020b) we can determine that the number of passengers using public transport grew by $9 \%$ from 2009 to 2019. Taking the method of regression analysis, we can see a strong relationship between the number of passengers registered in public transport and the number of tourists $(r=0,87)$. Also, a similarly strong relationship can be observed between the number of passengers and citizens in Budapest $(r=0,86)$.

According to the World Commission on Environment and Development (1987) sustainability is a complex process, where the fulfilment of the needs of the current population is ensured without damaging the fulfilment of the needs of the future generations. This means, that transportation should be used in a way that we do not endanger for example the need for the health and healthy life and environment of the future population.

Based on the opinion of Rodrigue (2020) sustainable transport means the development of sustainable transport modes, infrastructure, and operations. In terms of development three main dimensions are taken into consideration: environmental, economic, and social. If we consider the environmental dimension, we can think about the reduction of pollution and noise, while sustainable economic development includes new jobs for citizens and the contribution of transportation to the growth of the economy. By observing the social dimension, safety and health come into mind.

Of course, the growing traffic in Budapest and also in the agglomerations will result in conflicts and further problems. If we think of the disadvantages of traffic, the first thing that comes to mind is pollution. It is indisputable that the extent of air pollution depends on the time of day as due to commuting more cars are on the streets during the morning and afternoon. Based on the research of the Hungarian Meteorological Service (2020) the air quality of Budapest is marked as good or excellent in all the measured areas, however, the research emphasizes that with regards to flying dust (PM2.5) at Dózsa György street the maximum daily average value $(55,4 \mu \mathrm{g} / \mathrm{m} 3)$ has reached the yearly health limit $(25 \mu \mathrm{g} / \mathrm{m} 3)$. According to the research of the European Public Health Alliance (2020) Budapest loses more than 3200 million Euros (around 6,2\% of the GDP) per year due to air pollution (Figure 1). 


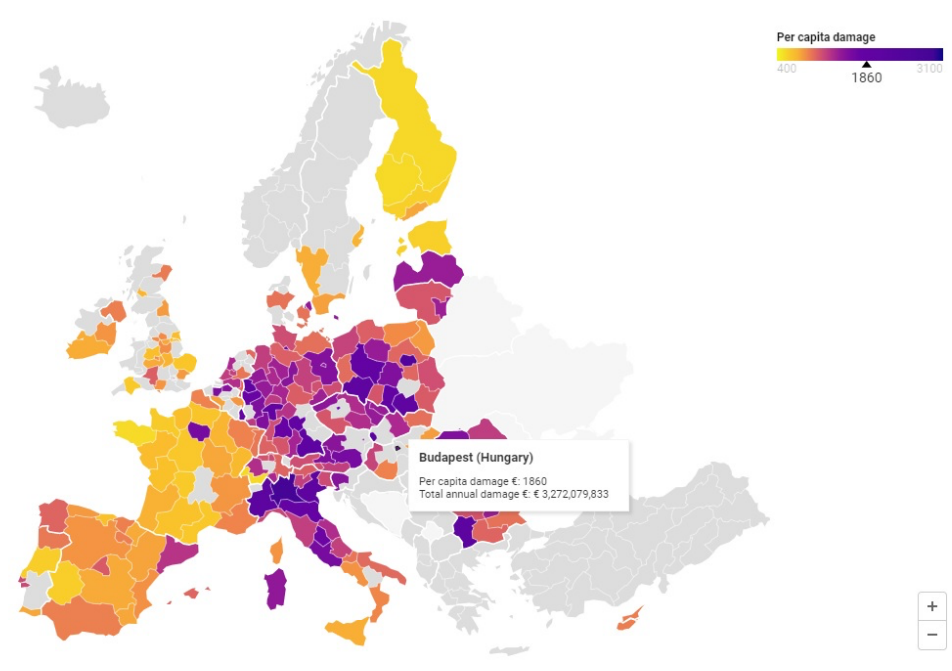

Source: EPHA (2020)

If we compare only the capitals, Budapest is at the 8th place, only London, Bucharest, Berlin, Warsaw, Rome, Paris, and Madrid are before us. If we review all the examined 432 cities, Budapest is the 22nd in the ranking. The pandemic brought its advantage with regards to air pollution as working places introduced the possibility of home office where it was possible, so fewer citizens need to commute to their working place on a daily basis. Home office and further governmental restrictions contributed to the decrease of air pollution. Earther has created an interactive map (Figure 2) which shows the quality of air across the world.

\section{Figure 2: Air pollution in Hungary}

\subsubsection{0}


It is visible that the most polluted areas (marked with red) decreased until March. With respect to Budapest, according to the measurement conducted on 21st February 2020 the air of our capital was more polluted, the yellow colour is more powerful, also a small red dot can be seen. If we compare the result with the measurement conducted on 20th March 2020, we can see that the red dot disappeared and the yellow colour became paler as well which shows that the quality of the air was getting better. This may be an indirect evidence that less traffic contributes to improving air quality.

But if we speak about pollution, we should think of noise pollution as well which is a negative side effect of increasing traffic. Continuous high or extremely high noise may be harmful for the health of citizens. Based on the research of the Herman Ottó Nonprofit Institute (2017) 57,72\% of the citizens in Budapest are affected by noise pollution caused by road traffic during the day, where the level of the noise is more than $55 \mathrm{~dB} .60 .400$ citizens suffer from extremely high noise pollution in the daytime, where the level is more than $75 \mathrm{~dB}$ which is really harmful, as it may cause hearing loss in long run. This number decreases to 9.200 during the night. The number of affected citizens grew by 41.800 from 2011 to 2016 . If we review only those who are affected by more than $75 \mathrm{~dB}$, the number grew by 8.200 within 5 years. If we review railway traffic, only $4,51 \%$ of residents are affected by noise pollution, furthermore none of them suffer from the extremely high noise (with more than $75 \mathrm{~dB}$ ). Surprisingly only $0,04 \%$ of residents in Budapest are affected by noise pollution, the level of the noise is mainly between 55-60 dB. This data may be confusing as the airport is located near Vecsés, where citizens may be affected by noise pollution caused by the air traffic but they are not calculated in this current research.

Another main issue caused by the traffic in Budapest is congestion. According to the research of INRIX (2020) drivers in Budapest lost 92 hours in traffic jams in 2019. Fortunately, this timeframe has decreased by 6\% from 2018 to 2019 but increased by 10\% from 2017 to 2018. With this, Budapest occupied the 17th place in the ranking of European cities. Nevertheless, congestion may result in costs for the drivers and for the cities as well according to the study. Unfortunately, the research paper detailed only few countries, but it clearly shows the economic impact of congestion in the cities. If we take German cities, Munich is the city most affected by congestion: Drivers lose 87 hours while sitting in traffic jams per year, and this resulted in an average cost of 774 Euros per driver in 2019 and an average cost of 405 million Euros for the city in the same year. As we can see, congestion has economic impacts, as drivers cannot work and contribute to the economic life while they are spending this time in their car. Furthermore, congestion has environmental impacts as well. Cars undoubtedly pollute the 
air. When cars wait in traffic jams, some drivers do not stop operating the motor of the vehicle, so they emit pollutant materials continuously. On top of that, as cars stay at the same place, the pollutants concentrate in those areas.

The increase of traffic may lead to an uninhabitable city. The deteriorating quality of air, increasing noise, crowds have a negative impact on the quality of life. The Economist Intelligence Unit (2019) prepare the Global Liveability Index on a yearly basis. This research takes the quality of the road network and the quality of public transportation into consideration in the infrastructure section. The problem of this research concerning transportation is that only the previous two aspects are examined, while many other aspects influence the quality of the life of residents, such as the previously mentioned air and noise pollution or congestion. Based on the research, Budapest has been the most liveable city in Eastern Europe for several years. Also, since 2010 Budapest could improve its ranking with 20 places: among 140 cities across the world Budapest occupied the 35th place in 2019. Unfortunately, due to the lack of details the exact reason of the improvement cannot be identified, it may be the healthcare or the infrastructure and so the transport system as well. However, based on the EIU research Budapest is more and more liveable, still some citizens decide to move to agglomerations which will contribute to increasing traffic on the roads due to commuting.

The lack of parking places has been the main problem for drivers for several years but from the point of view of sustainability it raises some questions. The number of cars is increasing year after year but building parking lots have limits. As the number of the cars increase more intensively than the number of the parking lots in Budapest, finding a place is quite difficult. Building more parking lots may create adverse feelings in citizens. Parking lots take extra place away from the residents and also green areas could be eliminated which disrupts the harmony of the environment. As green areas, trees are eliminated (which actually clean the air of the city), the temperature near the ground increases which may cause uncomfortable feelings when passing through those areas.

As new methods of transport appeared during the past years, various types of vehicles are seen on the streets of the city. Residents should pay more attention when they are on the street but there is more news about incidents and conflicts between citizens using different means of transportation. Fortunately, the registered number of incidents decreased by $20 \%$ between January and September 2020 compared to the same period the year before. However, I should mention that those are only the registered incidents. The number is still more than 2.000 in spite of the fact that due to the pandemic there was a period when less cars were on the streets after the introduction of home office. 


\section{Methodology}

In my research mainly the environmental and social dimensions were in focus. My aim was to get a clear picture of the opinion of the citizens of Budapest and those who visit our capital regularly (for example for work). Two separate research was conducted, where the second one was in connection with the results of the overtourism in Budapest, taking the transportation dimension into consideration as well. For both research quantitative methods were used. Online questionnaires were prepared which were shared on social media, focusing on such groups, who are interested in transportation and its improvement in Budapest.

The first questionnaire which examined the opinion of the citizens concerning the aspects of transportation in Budapest which need improvement was filled out by 289 respondents $(N=289) .29,1 \%$ of the respondents were between the age of $18-25$ years, the second largest group $(20,1 \%)$ was between $51-60$ years. The age group $31-40$ was represented by $19,7 \%$, while $15,6 \%$ of the respondents were between $26-30$ years and citizens between 41-50 years were represented by the same ratio.

With regards to their educational attainment, $45,2 \%$ hold bachelor degrees and $51,1 \%$ finished their secondary education. $2,5 \%$ of the respondents finished their $\mathrm{PhD}$ studies and the percentage of those who hold master's degrees amounts to $2.5 \%$ as well. $1,2 \%$ of the respondents finished their vocational training.

$75,3 \%$ of the respondents live in Budapest, $16 \%$ live 31 kilometres or farther from our capital. $4,9 \%$ of the respondents live in the 11-20 kilometre range from Budapest. $3,8 \%$ of the respondents live maximum 10 kilometres from the city and the same ratio is represented by those who live in the 21-30 kilometre range from Budapest.

The largest group of the respondents $(89,9 \%)$ work in Budapest and 8,9\% work 31 kilometres or farther from the capital. 1,2\% of the citizens work 11-20 kilometres far from the city.

The other questionnaire which examined the attitude of the citizens towards tourism, more precisely overtourism in Budapest and its impacts on the transport system and infrastructure was filled in by 244 respondents $(N=244)$. Here the age group $31-40$ years was represented by $30,4 \%$ and the second largest group (25\%) was between $26-30$ years. $19,6 \%$ of the respondents were between $41-50$ years while $10,7 \%$ were between $51-60$ years. Only 8,9\% were between $18-25$ years and 5,4\% between $61-70$ years.

$75 \%$ of the respondents live in Budapest, $16,1 \%$ live in Pest County and only $8,9 \%$ live in other parts of our country. The largest group (42,9\%) was born in Budapest, 
$19,6 \%$ do not live in our capital. $16,1 \%$ of the respondents have lived in our capital for more than 11 years.

If we consider the place of work, $87,5 \%$ work in Budapest, $8,9 \%$ work in other parts of the country and only $3,6 \%$ work in Pest County.

\section{Findings}

First of all, I was interested in the type of transportation citizens use to get from where they live to where they work. The place of working and living is quite important as it determines commuting. Here I have distinguished two groups: one, if the working and living place were in the same settlement and two, if the citizens had to commute between the two places as they live and work in different settlements. If the working and living places are not in the same settlement, residents mainly use public transportation services (45,7\%). 40,5\% of the respondents use their own car. $16 \%$ of the citizens commute by train between the two places and $10,4 \%$ use the bus service. $4,1 \%$ ride their bicycle and 2,5\% use their own motorcycle.

If the place of living and work are the same, respondents use the public transportation system $(75,2 \%)$. The second largest group $(24,1 \%)$ use their own car to get to work. $9,2 \%$ of the respondents use bicycles to get to work. Various types of transportation methods are represented in the other section which can forecast a kind of change in the mindset of the citizens. Some respondents use electric rollers or car sharing. For 1,2\% of the respondents the employer provides company buses which collect the employees and take them to their working place.

From those respondents, who use their own car to get to their work, 52,1\% would never resign using their own car on a daily basis because of environmental considerations. 36,3\% said that maybe they would change from their own car to public transportation to be more environmentally friendly. 11,6\% would rethink the method of the commuting and would switch from their own car to the public transportation service. The above results show a quite negative picture as the largest group uses their own car on daily basis and most of them would not change their daily routine and take another means of transportation to protect the environment.

I have examined the aspects which make cars more competitive than public transportation as a means of commuting. The main reason to take the car is that users are not bound by a timetable, they can have their own schedule. The other main reason is speed, they can get from one point to the other within less time. The above two attributes are the main and most important reasons to take the car. Another impor- 
tant factor for using the car is predictability, as 35,6\% marked it as a really important motivation. This means, that the route can be planned on their own and it is easier to insert further breaks and stops or change the route immediately if needed. Comfort also plays an important role when driving a car, the private sphere is not disturbed, or other passengers are friends or family members. It is an interesting fact, that environmental consciousness is indicated by $25,20 \%$ of the respondents as an important factor for choosing their car which may cause feelings of resentment, as usually automobiles are not considered as environmentally friendly, however, electric or hybrid cars are more and more popular. $29,1 \%$ also take the cost into consideration when they decide to take the car. If citizens take the public transportation, they should take the price of the tickets into consideration while in case of cars fuel, insurances and other additional costs come into the picture.

Furthermore, I have researched those disadvantages, which may be considered as a push factors towards the car. $80,1 \%$ of the respondents are aware of the overcrowded transportation vehicles. Nowadays this may play an even more important role, as during the pandemic people pay more attention to their health and rethink their daily life and would prefer those kinds of transportation methods where fewer people travel together. The second main disadvantage is the delay of the public transportation vehicles. Citizens are afraid, that due to traffic jams or break downs they will be late from work or home. $58,9 \%$ of the respondents marked the slowness of public transportation as a negative attribute. On the other hand, passengers should calculate with the waiting time as well, although an increasing number of separate lanes are created for public transportation vehicles to get faster from one point to the other, while cars are stuck in traffic jams. $38,5 \%$ of the citizens think that the condition of public transportation vehicles is not attractive. For many years, the average age of the vehicles was quite high, but a positive trend is that the change of the vehicle fleet (buses and subways cars for example) is in progress where environmental awareness also plays an important role. $27,2 \%$ of the respondents take the car as the public transportation stops are far from the working place or home. $11,9 \%$ think that the cost of the public transportation is too high, higher than the costs of maintaining a car.

I was interested in what respondents think about the introduction of congestion charge. $28,5 \%$ of the respondents fully agree with the introduction of congestion charge in Budapest. 15,4\% agree as well, however, their opinion is not so markedly strong. $22,6 \%$ of the respondents have their doubts regarding congestion charge, they would introduce it but with some restrictions. 19,3\% would reject it and 14,2\% are fully against it. I have examined whether those who use their own car agree with or reject the idea 
of congestion charge. Respondents could mark on a scale from 1 (fully disagree) to 5 (fully agree) their opinion. The average score of those who use their car on (almost) daily basis is 2,61 which means that mostly they are against the charge.

It is still a question whether the congestion charge would decrease the car traffic in the city. $28,4 \%$ of the respondents think, that it would have an effect on the traffic but its extent is not clear. $23,5 \%$ say that its impact would be insignificant, the traffic would be the same. However, $18,5 \%$ of the respondent think that a congestion charge would have an influence on the decrease of Budapest's traffic. A further 17,3\% fully agree that the charge would have a strong effect which means that it could help decrease traffic. Only $12,3 \%$ say that there would not be any impact.

If a congestion charge were introduced, it would mean extra expenditure for those citizens who take their car. It is an interesting question whether these residents would resign their vehicle and change to the public transport service, once the congestion charge is introduced. $47 \%$ of those who drive to work $(N=138)$ might change to the public transport system but their mind is not completely made up yet. There might be several other factors which affect their decision, like the amount of the congestion charge, frequency of the payment. $41 \%$ said that they would not change to the public transport service once the charge was introduced. Only $12 \%$ would change their daily habit and instead of driving a car they would take the public transport.

If we speak about the congestion charge, it could be a fix amount for all drivers, or there might be various categories. $57,6 \%$ of the respondents said that it would be necessary to apply different tariffs (for example higher rates for buses) but $42,4 \%$ think that categorization and so tariff-differentiation is not needed, everybody should accept the same burden independent of the type of car for example. From those who would like to differentiate in the congestion charge $(N=166), 71 \%$ have the opinion that the charge should depend on the type of the vehicle, drivers of larger ones should pay higher charges. $65,7 \%$ think that the charge should be higher in proportion to the pollutant emission of the vehicle, which means the higher the emission is, the more the congestion charge should be. $59,2 \%$ remarked that the congestion charge should be higher in frequented routes and districts. $43,8 \%$ is of the opinion that the congestion charge should be differentiated according to a settled time zone, so during the rush hours the congestion charge should be higher. $34,3 \%$ of the respondents remarked, that the charge should vary in accordance with the number of the passengers in the vehicle, meaning the lower the number, the higher the tariff. Few respondents mentioned that higher number of passengers should mean higher charges, however, this opinion is calculating only with the amount of the charge which may be shared among more people 
but does not take the fact into account, that the amount of pollutant emission is higher per person when only one person is sitting in the car.

Different vehicles can disturb the citizens to various extents, which may depend on which vehicle type is the most common in an area. This impact may be considered as a social effect of transportation as well, which has been examined as part of the research too. $28,9 \%$ of the respondents remarked that cars are disturbing in their area and a further $24,1 \%$ mentioned that their daily life is disturbed largely. It seems that public transportation vehicles are not irritating the citizens, only $12,2 \%$ said that they are really disturbing. Similarly to public transportation, inbound buses are not annoying the citizens, only $6,9 \%$ are affected by the pollution (noise or other pollutant emission) of the buses. Tourist buses are more irritating for citizens, 32,9\% of the respondents said that they have a negative impact in their area. $62,4 \%$ suffer from the negative impact of motorcycles which pass their area on a daily basis. The research shows that trains are not disturbing the citizens. $80,9 \%$ said that flights are not disturbing in their area. This result was surprising as from last year the arrivals and departures were banned at the airport of Budapest. A deeper research would be useful to analyse this issue as probably respondents are not living in the area of the airport. The results show that ships do not disturb the citizens in any way.

I also researched the opinion of the citizens with regards to the measure of air pollution of the different transportation methods. $89,5 \%$ of the respondents remarked that cars are pollutant vehicles and I received a similar result for motorcycles as well where $88,2 \%$ think that they have a negative impact on the air of the city. Although respondents remarked that tourist buses are not irritating them, $92,6 \%$ said that they have a hugely negative influence on air quality. $74,4 \%$ remarked that public transportation vehicles pollute the air of our capital as well. $71,9 \%$ of the respondents think that inbound buses pollute the air of Budapest as well. $81,8 \%$ said that flights have a polluting impact on the air. Surprisingly, the results show that in the opinion of the respondents flying is not the most polluting way of transportation. The result shows that the most eco-friendly transportation method is the train. Only $14 \%$ said that they have a negative impact on the quality of the air. 52,7\% remarked ships were also polluting, which shows that although ships do not disturb the citizens they still know about their negative impact on air even if they are just standing anchored (as heating, electricity are still needed for example).

In my research I have also examined the opinion of the citizens, concerning the measures that would contribute to the improvement of the air quality in Budapest. $92,2 \%$ of the respondents think that the public transportation vehicles should be up- 
graded as their average age is quite high, and older vehicles have higher pollutant emission. $82,1 \%$ said that cars should be banned in certain areas of the city and $79,8 \%$ think that car traffic should only be regulated and so decreased in some areas. $82,1 \%$ of the respondents think that more Park and Ride areas should be created, however, if we look at the previous results, the largest group said that they would not take the public transportation instead of their car to protect the environment. $62,8 \%$ of the respondents marked the congestion charge as one of the best measures to protect the quality of the air in the capital. While $52,7 \%$ said that ships are polluting the air of Budapest, $60,4 \%$ think that ship traffic should not be regulated and decreased. 55,6\% of the respondents think that public transportation vehicles should be banned as well in certain areas of the city. $61,6 \%$ remarked that the number of flights should be restricted. $74,9 \%$ think that railway stations should not be relocated outside the city centre, while $68,1 \%$ said that the location of the bus stations should not be changed.

Furthermore, I have examined, which of the above measures would or would not be supported by the respondents in order to improve the quality of the air in Budapest. $100 \%$ of the respondents said that they would strongly support the improvement of the quality of public transportation vehicles. $89,2 \%$ remarked that they would favour the construction of Park and Ride parking areas. $74,5 \%$ said that restriction on the number of cars would be useful but only $36,8 \%$ believed that banning car traffic would be supported. $60,7 \%$ would agree with the introduction of a congestion charge. $35,8 \%$ would favour the restriction of the number of ships on the Danube and $47,2 \%$ would restrict the daily number of flights. Relocating railway and bus stations outside the city would not be supported by most of the respondents.

The question of which area should be improved in Budapest and its agglomerations is also interesting. $67,8 \%$ said that both the system and infrastructure of the traffic in Budapest and its agglomerations should be improved. $17,8 \%$ would only improve the situation in the suburban areas of Budapest and 13,2\% would focus only on the infrastructure of Budapest. Only 2,3\% of the respondents are satisfied with the transportation system and infrastructure, they would not improve any of their aspects. $77,2 \%$ of the respondents would improve the road network and its condition. $62,6 \%$ would focus on railway connections and also the same percentage would improve public transportation availability in their area. 34,1\% think that bicycle roads should be built. $34,9 \%$ would improve bus connections. In the other section of the questionnaire mainly the social sensitization between the drivers and cyclists was mentioned.

In a nutshell, the first questionnaire shows that cars are one of the most popular vehicles for travelling between places, especially if the working place is located further 
from the living place. Environmental awareness seems to be increasingly important in the daily life of people but taking the results into consideration we can establish that cars are so much preferred and practical that residents would not resign their use to protect the environment. If traffic is to be decreased in the capital, it would have a positive impact on air quality. The largest group of respondents thinks it is cars that mostly pollute the air of Budapest. It is an interesting fact that $62,8 \%$ think a congestion charge would contribute to the decrease of air pollution but only $35,8 \%$ remarked that it would have an impact on the traffic. These two questions should show similar results as the air quality could improve only if the traffic decreases on the streets. Another interesting fact is that although $60,7 \%$ would support the introduction of a congestion charge, $41 \%$ would not resign the use of their car in spite of the fact that $53 \%$ of the respondents are disturbed by the noise and air pollution caused by cars, which have a huge, negative impact on their daily life.

The second research examined the impact of overtourism on the traffic of Budapest. As discussed before, tourists also use the infrastructure of the city, thus the transportation system as well and this phenomenon may be observed by the citizens as well. As mentioned above, the number of tourists was continually increasing in the years before the pandemic. $16,1 \%$ of the respondents say they are not impeded in their transportation, while $21,4 \%$ of the respondents are impeded but only in a minimal way. $14,3 \%$ said that the increasing number of tourists is an irritating factor during their transportation, which means that the social dimension of the sustainable transportation is violated. $16,1 \%$ mentioned that the obstacles caused by the number of tourists are significant. If the respondents are hindered during their transportation, the largest group (62\%) mentioned traffic jams, being held up on the streets or the lack of space as the main problems. Another frequent issue (mentioned by $48 \%$ ) is the extended traveling time which may be caused by the previously mentioned traffic jams as well.

$41 \%$ of the respondents felt that the number of tourist buses increased in Budapest. $33,9 \%(N=92)$ mentioned that they acknowledged the increase but it was not significant, while $7,1 \%$ of the respondents feel that the number of tourist buses increased dramatically. As we can see from the above research, tourist buses disturb $32 \%$ of the citizens which means that they recognize the increasing trend and also feel the negative effects.

With regards to water transport, 30,4\% recognized the increasing number of river cruises on the Danube, while 55,4\% mentioned that a certain growth can be measured but the amount was not significant. 
$68,6 \%$ of the respondents think that the increasing number of tourists contribute to the overcrowdedness of public transportation which means, that local residents may be displaced from the service. This is a clear violation of the social dimension of the sustainable development of the transport system. $46,4 \%$ said that overtourism contributes to traffic jams in Budapest having a negative impact on the quality of the air as well, which has been mentioned by $53,6 \%$.

\section{Conclusion}

The number of residents and the number of tourists increase year after year which affect the transport system of our capital. The increasing traffic in Budapest causes various issues in our capital which have an effect on the quality of life of the residents. One of the main problems is air pollution which causes huge losses for the city as well. More than $57 \%$ of the residents in Budapest are suffering from noise pollution which has a harmful effect on their health on the long run. Congestion also contributes to air pollution, furthermore, research shows that residents spend more than 90 hours sitting in their car during which time they are not productive. Pollution and congestion may lead to an uninhabitable city. Although the ranking of Budapest improved year by year, the method of research did not take many aspects of transportation into consideration. New modes of transportation appeared during the past years which lead to conflicts on the streets. The number of incidents in Budapest decreased comparted to last year but it should be highlighted that due to the pandemic many citizens took the opportunity and worked from home.

The most popular method is public transport both among those whose working place and place of the residence is the same and those whose working place and place of residence differ, while the second most popular way of traveling is the car. The result shows that citizens would not resign the use of their car if it was for protecting the environment. If the improvement of the public transport is planned, speed and frequency should be taken into consideration, furthermore punctuality and less crowded vehicles should be in the focus as well. Few years ago, the introduction of a congestion charge was brought up to reduce the traffic in Budapest and the largest group of respondents agreed with this measure, however, those who mainly drive their car are against it. The amount of the congestion charge should be set so that it would incite car owners to take the public transport instead as the result shows that drivers would not change even if the charge was introduced. It would be useful to diversify the congestion charge, with several points taken into consideration, but the type of vehicle or the pollutant emis- 
sion could be the basis of the diversification. The most disturbing vehicles are cars and motorcycles, both in terms of noise and air pollution. These are also the most pollutant vehicles in the opinion of the respondents. The most important measure which could contribute to the improvement of the air quality is the renewing of the vehicle fleet of the public transport as older vehicles are more polluting. Also due to the fast improvement of the technology vehicles using alternative fuels or electricity are already available. These may cost more of course but the amount paid for environment protection could be saved in the long term. Some electric buses can be seen in Budapest and the average age of transport vehicles is decreasing due to the purchase of new ones. Regulation or banning of car traffic would also contribute to the improvement of air quality. As for the public support of measures, respondents would agree with the improvement of public transport vehicles or the regulation of car traffic in certain areas. Park and Ride parking lots are supported as well, however as we have seen, drivers would not give up using their own car. Smart parking should be taken into consideration, where again technical improvements and also mobile technology could be used. As mentioned, tourism is a growing industry and tourists are using the same transport infrastructure as local residents. The growing number of tourists disrupts residents' transport habits which should be taken into consideration as well, as socially this situation cannot be considered sustainable.

In summary sustainable points of view should be taken into consideration with regards to residents but on a municipality and operational basis. Some minor steps might have been taken but in the long run the mindset of the residents needs to change as well, as everybody should contribute to sustainable transportation. It would be essential to introduce the congestion charge as Budapest has committed to do so when the construction of Metro Line 4 was started. Additionally, those residents who contribute more to air pollution, should be obligated to pay the costs or part of the costs of damage control. In some kind of transportation methods we can see such trends. Airlines already offer the opportunity to calculate the ecological footprint of our travel and we can pay an extra fee to compensate it. On top of the congestion charge, the infrastructure of the public transport needs to be improved as it could make the system more attractive and residents might prefer to use it than their cars once the congestion charge is introduced. 


\section{References}

Danube Region Strategy (2019). Study of the development of the cruise tourism in the Danube Region [on-line]. Retrieved from: https://danube-region.eu/wp-content/ uploads/2020/01/Cruise-Tourism-in-the-DR Report ENG.pdf (retrieved on: 31. 10. 2020).

European Public Health Alliance (2020). Health costs of air pollution in European cities and the linkage with transport [on-line]. EPHA. Retrieved from: https://cleanair4health.eu/wp-content/uploads/sites/2/2020/10/final-health-costs-of-air-pollution-in-european-cities-and-the-linkage-with-transport-c.pdf (retrieved on: 01.11. 2020).

Herman Ottó Nonprofit Institute (2017). Budapest Fővárosra 2017 - Stratégiai Zajtérkép Megújítása [on-line]. Vibrocomp. Budapest. Retrieved from: https://zajterkepek.hu/ media/Budapest zajterkep 2017 1169.pdf (retrieved on: 01. 11. 2020).

Hungarian Central Statistical Office (2016). Az ingázás kiemelt célpontjai [on-line]. Budapest: KSH. https://www.ksh.hu/docs/hun/xftp/idoszaki/pdf/ingazas.pdf (retrieved on: 01. 11.2020).

Hungarian Central Statistical Office (2019). Repülőterek forgalmi adatai [on-line]. KSH. Budapest. Retrieved from: http://statinfo.ksh.hu/Statinfo/themeSelector. jsp?lang=hu (retrieved on: 31. 10. 2020).

Hungarian Central Statistical Office (2020a). Közúti gépjármü-állomány, december 31. (2000-) [on-line]. Retrieved from: http://www.ksh.hu/docs/hun/xstadat/xstadat eves/i ode006b.html (retrieved on: 29. 10. 2020).

Hungarian Central Statistical Office (2020b). A helyi személyszállítás országos és budapesti forgalma közlekedési módok szerint (2001-2019) [on-line]. Retrieved from: http://www.ksh.hu/docs/hun/xstadat/xstadat eves/i odme006.html (retrieved on: 29. 10. 2020).

Hungarian Meteorological Service (2020). Az OLM 2019. évi szálló por PM10 és PM2.5 mintavételi programjának összesítő értékelése. OMSZ. Retrieved from: http://www. levegominoseg.hu/Media/Default/Ertekeles/docs/2019 PM10 Pah nehezfem.pdf (retrieved on: 29. 10.2020).

INRIX (2020). Global Traffic Scorecard [on-line]. INRIX. Retrieved from: https://inrix. com/scorecard (retrieved on: 01. 11. 2020).

Jászberényi M. (2019). Vízi turizmus és közlekedés: Termékek, trendek, regionalitás [on-line]. Budapest: Akadémiai Kiadó. Retrieved from: https://mersz.hu/dokumentum/m522vituk 1/ (retrieved on: 28. 10. 2020). 
Rodrigue, J-P. (2020). The geography of transport systems [on-line]. New York: Routledge. Retrieved from: https://transportgeography.org/?page id=6263 (retrieved on: 28. 10.2020).

The Economist Intelligence Unit (2019). The global liveability index 2019 - A free overview [on-line]. EIU. Retrieved from: http://www.eiu.com/Handlers/WhitepaperHandler.ashx?fi=Liveability-Free-report-2019.pdf\&mode=wp\&campaignid=liv eability2019 (retrieved on: 02. 11. 2020).

Turizmus.com (2019). Megszünnek az éjszakai repülések Budapesten [on-line]. Retrieved from: https://turizmus.com/utazas-kozlekedes/megszunnek-az-ejszakairepulesek-budapesten-1165370 (retrieved on: 29. 10. 2020).

World Commission on Environment and Development (1987). Our common future [on-line]. Oxford University Press. Retrieved from: http://www.un-documents.net/ our-common-future.pdf (retrieved on: 28. 10. 2020). 